\title{
RESEARCH ON RUNOFF SIMULATION IN NINGXIA SECTION OF THE YELLOW RIVER BASIN BASED ON IMPROVED SWAT MODEL
}

\author{
WANG, Z. ${ }^{1,2,4, *}-$ TIAN, J. ${ }^{1,3,4}-$ FENG, K. ${ }^{1,3,4}$ \\ ${ }^{1}$ College of Civil and Hydraulic Engineering, Ningxia University, Yinchuan 750021, China \\ ${ }^{2}$ School of Mathematics and Statistics, Ningxia University, Yinchuan 750021, China \\ ${ }^{3}$ Ningxia Research Center of Technology on Water-Saving Irrigation and Water Resources \\ Regulation, Yinchuan 750021, China \\ ${ }^{4}$ Engineering Research Center for the Efficient Utilization of Water Resources in Modern \\ Agricultural in Arid Regions, Yinchuan 750021, China \\ (phone: +86-13895005003) \\ *Corresponding author \\ e-mail:wang_zp@nxu.edu.cn
}

(Received 29 $9^{\text {th }}$ Aug 2018; accepted $7^{\text {th }}$ Nov 2018)

\begin{abstract}
In recent years, the Ningxia Section of the Yellow River Basin of China has become waterstressed due to the reduction of the upstream precipitation, to the serious water and soil loss in the midstream, to the increased water consumption in industrial and agricultural areas and to other reasons. To fully understand the runoff variation of the Yellow River in the Ningxia Section of China and to rationally carry out the water dispatching and the water resource management, the applicability of the SWAT model for water balance in this basin is explored. Based on the improved SWAT model, the distributed hydrological model of the Ningxia Section of the Yellow River Basin of China has been constructed. The meteorological and hydrological data of the Ningxia Section of the Yellow River Basin of China from 1990 to 2017 have been used for simulation. The relative error $R_{e}$, the correlation coefficient $R^{2}$ and Nash-Suttcliffe coefficient Ens have been used as the standards, while the sensitive parameter of the measured monthly runoff from 2005 to 2011 to the model used for the calibration, and the model have been validated by the measured monthly runoff from 2012 to 2017 . The research results show that the simulation results basically meet the model evaluation requirements, indicating that the SWAT model is applicable to the runoff simulation of the Ningxia Section of the Yellow River Basin of China, and it can provide decision-making basis for water resource management in the Ningxia Section of the Yellow River Basin of China.
\end{abstract}

Keywords: SWAT model, Yellow River Basin in Ningxia Section, runoff simulation, hydrological modeling, water resource

\section{Introduction}

The water quality and quantity play a very important role in the aquatic ecosystem. To protect the river ecosystem, the scientific hydrological knowledge is required (Armanini et al., 2011); a Canadian Ecological Flow Index was developed based on benthic macroinvertebrate flow sensitivity index for Canadian rivers. The river runoff plays a pivotal role in water quality and ecology, including phytoplankton, zooplankton and Bacterial communities (Godlewska et al., 2003; Sokal et al., 2010; Wu et al., 2015), and also including hydrological indicators and their application to ecological management and research, such as basin or river health assessments (US EPA, 2015; Biggs et al., 2002). 
Hydrological systems are complex and difficult to understand. To overcome these difficulties, hydrologists have studied hydrological systems with a simpler approach that is the hydrological model (Xu, 2002; Woessner, 2012). To research the different influencing factors of hydrological systems, the hydrological model has been continuously improved (Chow et al., 1988). In order to clarify some of the characteristics of the hydrological system, the hydrological model is used to simulate hydrological systems in the basin under climate change conditions, such as climate change, land use and soil (Leavesley et al., 1983; Viessman et al., 1989).

The SWAT (Soil and Water Assessment Tool) model was used to simulate the hydrological processes in the research area as they are influenced by the input data, namely slope, soil, land cover and climate. The SWAT model is the one used for simulating hydrological processes, and related to the input data, soil, climate and land use, as well as other factors. The SWAT model is a distributed watershed hydrological model developed by the Agricultural Research Service (ARS) of US Department of Agriculture (USDA) (Arnold et al., 1998). It is currently a relatively advanced international watershed hydrological model, and this model is mainly used to simulate the water quality and quantity of surface water and groundwater. It can predict the impact of the land management measure on the yield of hydrology, sediment and agricultural chemicals in large and complex watersheds with various soils, land use and management conditions.

The SWAT model is widely used in the world. Schuol et al. (2008) have verified the applicability of the model in the Lunnehe Basin under different hydrometeorological and underlying conditions. Arnold et al. (1998) have verified the applicability of the model in the Mississippi tributary, etc. under different hydrological conditions, different topographic features and different time and space. Fohrer et al. (2017) have found that the land use change had the highest impact on runoff by simulating the Aare River Basin in Germany. Joel and Jiben (2012) have clarified the impacts of various land use patterns on runoff by studying the land use and cover change of the Wami Basin 13a in Tanzania. Nie et al. (2011) have studied the relationship between land use pattern and water balance in the special years of the San Pedro Basin, and found that the urbanization is the biggest influencing factor. Lin et al. (2015) have studied landuse change impacts on catchment runoff using different time indicators based on SWAT model. Lotz et al. (2018) have studied factors of runoff generation in the Dongting Lake basin based on a SWAT model and implications of recent land cover change. Liu et al. (2017) researched the impacts of manure application on SWAT model outputs in the Xiangxi River watershed, Tamm et al. (2018) studied the effects of land use and climate change on the water resources in the eastern Baltic Sea region using the SWAT model. The SWAT model has been modified and adapted to simulate the changes in landuse, fertilizer management and tillage management (Amon-Armah et al., 2013; Maharjan et al., 2016; Liu et al., 2013, 2014). With the best parameters, the SWAT model will be used to simulate the pollution conditions in the selected watersheds (Dechmi et al., 2012; Liu et al., 2016).

In this paper, to fully understand the runoff variation of the Yellow River in the Ningxia Section and to rationally carry out the water dispatching and the water resources management, the applicability of the SWAT model for water balance in this basin is explored. Based on the improved SWAT model, the distributed hydrological model of the Ningxia Section of the Yellow River Basin has been constructed. 


\section{Material and methods}

\section{Research area}

The Yellow River has the entrance in the Xiaheyan in Zhongwei City, Ningxia, China. It flows through Zhongning County, Qingtongxia City, Litong District, Lingwu City, Yongning County, Yinchuan City, Helan County, Pingluo County, Dawukou District and Huinong District, and flows into Inner Mongolia in Shizuishan. There are three hydrological stations on the main stream of the Yellow River, including: Xiaheyan, Qingtongxia and Shizuishan Hydrological Stations. The Yellow River Basin in Ningxia Section is located in the north latitude $36^{\circ} 0^{\prime}-39^{\circ} 23^{\prime}$ and east longitude of $104^{\circ} 17^{\prime}-107^{\circ} 39^{\prime}$, and the drainage area is $51400 \mathrm{~km}^{2}$. Its landform type is the alluvial plain of the Yellow River, and its terrain is flat; its ditches are vertical and horizontal, and its elevation is between 1100 and $2500 \mathrm{~m}$. It is a temperate arid zone with sufficient sunshine. The average annual sunshine hour in the Basin is 2750-2950 h, and the annual average wind speed is $1.7-2.5 \mathrm{~m} / \mathrm{s}$. Its temperature difference is large; the heat is rich, and the frost-free period is longer. The Basin is continental climate, with drought and little rain, and its average annual precipitation is $180-220 \mathrm{~mm}$. The annual precipitation changes are weakened from the north to the south. The monthly average difference of precipitation in its Yellow River irrigation area is relatively significant, and the distribution in the year is extremely uneven. The precipitations in arid area in central Ningxia and the southern mountainous areas are relatively flat during the year, showing the seasonal changes. The precipitation in the Basin is unevenly distributed during the year, and the dry and wet seasons are obvious. The precipitation in July-September accounts for $60 \%-70 \%$ of the annual precipitation, and its evaporation is strong, with an average annual evaporation of 1100-1600 mm. The land use types mainly include grassland and cultivated land accounting for $33.74 \%$ and $48.76 \%$ of the basin area respectively, while the forest land accounts for $3.60 \%$ of it, the water area $1.43 \%$ of it, the urban and rural industrial and mining resident land $1.46 \%$ of it, and the unused land $11.01 \%$ of it.

\section{Theory of the SWAT model}

The SWAT model has a sub-module for each link of the water cycle, and its design idea is advanced. Such design method is very beneficial for the expansion and application of the model. The model establishes an important connection between the river basin process and the land use activity. Therefore, the applicability of various decisions in the basin management can be evaluated. Different sub-models can be selected and used based on different research purposes. It is also very unique in its operation mode. The SWAT model uses a specific command code control method to control the evolution of water flow in the river network and between sub-basins.

According to the river network system, SWAT divides the studied basin into multiple sub-basins, and maintains the spatial relationship between the geographic location of basin and the sub-basin. There are different meteorological, hydrological, land use, soil, agricultural management measures and pesticide application in each sub-basin. Then, the sub-basin is divided into multiple HRUs (hydrologic response units) based on factors, such as land use type and soil type and their common attributes. The hydrologic response unit is used as the minimum hydrological simulation unit to simulate the various parts of the water cycle and its quantitative transformation relationship, and then the sedimentation, runoff and non-point source load of each hydrologic response unit in 
the sub-basin are summarized; finally, the water balance of the basin is obtained through the river network convergence calculation.

The SWAT model is essential for water balance in the basin simulation process. The hydrological simulation of the basin is divided into two parts: one is the land phase of the water cycle, which is mainly used to control the water, sediment, nutrients and pesticide amount; the other part is the calculation phase of the water cycle, which is used to define the movement of water, sand and other substances through the basin water network to the outlet part of the basin.

The SWAT model simulates the land phase of water cycle by using the following water balance expression:

$$
S W_{t}=S W_{0}+\sum_{i=1}^{t}\left(R_{\text {day }}-Q_{\text {surf }}-E_{a}-w_{\text {seep }}-Q_{g w}\right)
$$

where, $S W_{t}$ is the final soil water content $(\mathrm{mm}) ; S W_{0}$ is the initial soil water content $(\mathrm{mm}) ; t$ is the time step (day); $R_{\text {day }}, Q_{\text {surf }}, E_{a}, w_{\text {seep }}, Q_{g w}$ are respectively precipitation, surface runoff, evaporation, lateral stream flow of soil aquifer and infiltration amount, groundwater content $(\mathrm{mm})$ of the $i^{\text {th }}$ day.

The land phase of the water cycle of the SWAT model is mainly composed of meteorology, hydrology, sedimentation, vegetation growth, soil temperature, pesticides, nutrients and agricultural management, etc., while the calculation phase of the water cycle of the SWAT model is divided into two parts of the main channel and the reservoir, and mainly determines the transport movement of water, sand and other substances from the basin river network to the basin exit. The SWAT model has a number of modules that can be run separately or in combination with several of them depending on the object and content being simulated. The structural design adopted by the SWAT model is modular, which fully reflects the specific links from the beginning of precipitation to the formation of runoff in the basin.

\section{Construction of SWAT model database}

Before the simulation with the SWAT model, it is necessary to prepare relevant digital elevations, land use and soil maps and related database files to facilitate the generation of SWAT model input data sets. Considering the artificial disturbances, such as irrigation channels, drainage channels and river channels in the plain irrigation area, the SWAT model is improved in the extraction method of the ditch river network, the sub-basin and the division module of the hydrologic response unit. Specific practice includes that: according to the spatial distribution of natural river channels and artificial drainage ditch networks in the study area, the "burn-in" algorithm is used to sag the DEM. The principle of this method is to convert the digital river system and the drainage ditch network into the grid form, and its grid cell size is consistent with that of the original DEM. These grid cells are transformed into the unified coordinate system after the projection, and overlaid into the original DEM through the superposition. Keep the elevations of all grid cells in correction channel unchanged, and increase the elevations of the grid cells in non-correction channel perpendicular to the river direction by a small value, so that the elevation of the grid of the river channel is lower than the coastal elevation. Then, the modified DEM is processed again to generate a new basin 
river network. For the artificial water distribution channel, the DEM is processed by the principle of the elevation increment superposition algorithm. To make the sub-basin of the SWAT model in the irrigation area consistent with the irrigation area covered by the dry-drainage system in the irrigation area, and to avoid that too many sub-basins generated in the process of spatial discretization result in excessive spatial data conversion and calculation, the areas covered by the backbone channel and the drainage ditch are used as the dividing standards to set reasonable minimum channel catchment area threshold to divide the sub-basin, and then to divide each sub-basin according to the consistency of land use and soil type. Later, considering different crop planting structure, the farmland is refined to form the hydrologic response unit.

\section{DEM data}

The digital elevation model is essential when the SWAT model is used for basin division, water system generation and hydrological process simulation. The most common DEM map is grid type. Using DEM data can not only calculate the slope and slope length parameters of each sub-basin, but also define the basin river network. The channel slope, slope length and width of the basin river network and other characteristics are extracted from the DEM data. The basin river network can be used to determine the quantity and distribution of the sub-basin.

Most parts of DEM are relatively smooth terrain surface models, but for the error and the existence of some special terrain, there are some concave areas on the surface of DEM, which leads to low-precision water flow direction and makes the original DEM data unable to meet the research needs. Therefore, before most of simulation experiments, the original DEM data will be filled in depression by the hydrological analysis model of ArcGis Software, and finally the non- depression DEM data meeting the research requirements will be obtained.

The high-resolution DEM data SRTM (Shuttle Radar Topography Mission) 90-meter resolution data used in this paper can be downloaded from the International Scientific Data Service Platform of the Chinese Academy of Sciences (http://datamirror.csdb.cn/index.jsp), and cropped within the scope of the study area, see Fig. 1 .

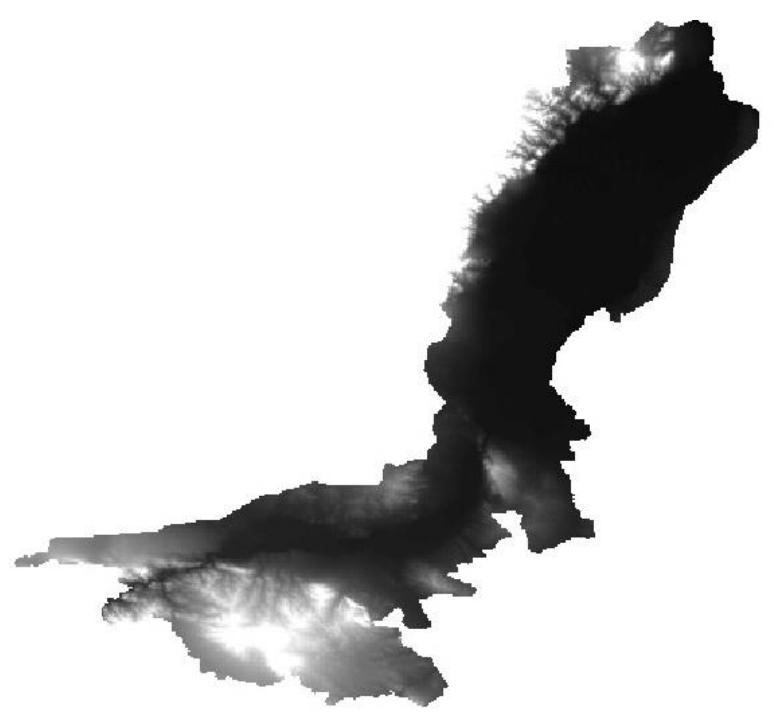

Figure 1. DEM Map of Ningxia Section of the Yellow River Basin 


\section{Land use data}

Using the SWAT model to simulate water resources in the basin and the land use map are very important. Humans will not easily change the topography and soil in the basin, but the land use will be changed by humans. Therefore, it is recommended to use the latest land use map for simulation. For the projection coordinate system of the land use distribution map, in case it is different from that set in the research, the projection module Projections of ArcToolbox needs to be used for projection transformation. The categories for land use map definition should be re-classified, and based on the classification determined by the SWAT's land cover/vegetation type database and the city database. Then a lookup table in the required format is generated to determine the code of each land use type on the land use map in the SWAT model (where 4 characters are required).

The national land use map collected in this paper is in shp format. It is first cut based on the boundaries of the basin, and then converted into the Grid format. Since the land use classification system of the SWAT model is classified based on the US classification system and is different from China's land use classification system, it is necessary to reclassify the land use types and convert the code in the land use map into the one that the SWAT model could identify. Refer to the Land Use Status Classification Standard (GB/T21010-2007) and the land use attribute database of the SWAT model, and then establish the land use database for the Yellow River irrigation area. The land use types reclassified are shown in Table 1.

Table 1. Reclassification Code Conversion of Land Use Types of the Basin

\begin{tabular}{|c|c|c|c|c|c|c|}
\hline \multicolumn{2}{|c|}{$\begin{array}{c}\begin{array}{c}\text { Original classification and } \\
\text { coding }\end{array} \\
\end{array}$} & \multicolumn{3}{|c|}{ Reclassification and coding } & \multirow{2}{*}{ Area $\left(\mathbf{k m}^{2}\right)$} & \multirow{2}{*}{$\begin{array}{c}\text { Percentage } \\
\text { of total area } \\
(\%)\end{array}$} \\
\hline No. & Land use type & Coding & Type in SWAT & SWAT code & & \\
\hline $\begin{array}{l}11 \\
12\end{array}$ & $\begin{array}{c}\text { Irrigated paddy fields } \\
\text { Dry land }\end{array}$ & 1 & $\begin{array}{c}\text { Agricultural } \\
\text { Land Generic }\end{array}$ & AGRL & 3750 & 45 \\
\hline $\begin{array}{l}21 \\
22 \\
23\end{array}$ & $\begin{array}{c}\text { Wood land } \\
\text { Shrubbery lands } \\
\text { Sparsely forested } \\
\text { woodland } \\
\text { Other forest land }\end{array}$ & 2 & Forest-Mixe & FRST & 217 & 2.6 \\
\hline $\begin{array}{l}31 \\
32 \\
33 \\
\end{array}$ & $\begin{array}{l}\text { Natural grass land } \\
\text { Improved grass land } \\
\text { Man-made grass land }\end{array}$ & 3 & Pasture & PAST & 1117 & 13.4 \\
\hline $\begin{array}{l}41 \\
42 \\
43 \\
46 \\
64\end{array}$ & $\begin{array}{l}\text { River surface } \\
\text { Lake surface } \\
\text { Reservoir surfac } \\
\text { Beaches and flats } \\
\text { Wet land }\end{array}$ & 4 & Water & WATR & 708 & 8.5 \\
\hline $\begin{array}{l}52 \\
51 \\
53\end{array}$ & $\begin{array}{c}\text { Residential quarters in } \\
\text { rural areas } \\
\text { Areas of cities and } \\
\text { town } \\
\text { Specially-used land } \\
\end{array}$ & 5 & Urban & URBAN & 393 & 4.7 \\
\hline $\begin{array}{l}61 \\
62 \\
63 \\
65 \\
66 \\
67 \\
67\end{array}$ & $\begin{array}{c}\text { Sandy land } \\
\text { Gobi } \\
\text { Saline-alkali land } \\
\text { Bare land } \\
\text { Exposed rock and } \\
\text { shingle land } \\
\text { Others } \\
\end{array}$ & 6 & Bare & BARE & 2154 & 25.8 \\
\hline
\end{tabular}




\section{Soil data}

The soil type charts collected in this paper is shp format. Same with the land use type, it is firstly cut based on the basin boundary, and then converted into the Grid format required for the model.

The soil types in Ningxia section of the Yellow River Basin mainly include the Light sierozems, Neo-alluvial soils, Aeolian soils, Calcic skeletal soils, Fluro-aquic soils, Wet fluro-aquic soils, Salinized fluro-aquic soils, Surface-rusted fluro-aquic soils, Cumulated There are 12 categories of irrigated fluro-aquic soils, Meadow solonchaks, Aquic irrigation silting soils, Surface-rusted irrigation silting soils, among which Light sierozems is the most widely distributed, accounting for $35.66 \%$ of the total area, followed by Aeolian soils and Neo-alluvial soils, Yellow River. The soil types and SWAT model codes of Ningxia section of the Yellow River Basin are shown in Table 2.

Table 2. Soil type and code table of Ningxia section of the Yellow River Basin

\begin{tabular}{|c|c|c|c|c|c|}
\hline Soil type & $\begin{array}{l}\text { Original } \\
\text { code }\end{array}$ & SWAT code & Soil type involved & Area $\left(10^{4} \mathrm{hm}^{2}\right)$ & Proportion \\
\hline Light sierozems & 23113112 & DHGT & Sierozems & 77.2 & 35.66 \\
\hline Neo-alluvial soils & 23115122 & XJT & Neo-alluvial soils & 36.8 & 17.00 \\
\hline Aeolian soils & 23115143 & FSHT & Aeolian soils & 39.7 & 18.36 \\
\hline Calcic skeletal soils & 23115194 & GZHCGT & Skeletal soils & 18.5 & 8.53 \\
\hline Fluro-aquic soils & 23116141 & CHT & Fluro-aquic soils & 2.6 & 1.20 \\
\hline Wet fluro-aquic soils & 23116144 & SHCHT & Fluro-aquic soils & 1.7 & 0.77 \\
\hline $\begin{array}{l}\text { Salinized fluro-aquic } \\
\text { soils }\end{array}$ & 23116145 & YHCHT & Fluro-aquic soils & 3.8 & 1.76 \\
\hline $\begin{array}{l}\text { Surface-rusted fluro- } \\
\text { aquic soils }\end{array}$ & 23116146 & BXCHT & Fluro-aquic soils & 1.7 & 0.80 \\
\hline $\begin{array}{l}\text { Cumulated irrigated } \\
\text { fluro-aquic soils }\end{array}$ & 23116147 & GYCHT & Fluro-aquic soils & 3.2 & 1.48 \\
\hline Meadow solonchaks & 23118101 & CDYT & Solonchak & 8.7 & 4.00 \\
\hline $\begin{array}{l}\text { Aquic irrigation silting } \\
\text { soils }\end{array}$ & 23119113 & GCHYT & $\begin{array}{l}\text { Irrigation silting } \\
\text { soils }\end{array}$ & 9.2 & 4.25 \\
\hline $\begin{array}{l}\text { Surface-rusted } \\
\text { irrigation silting soils }\end{array}$ & 23119114 & BXGYT & $\begin{array}{l}\text { Irrigation silting } \\
\text { soils }\end{array}$ & 13.4 & 6.19 \\
\hline
\end{tabular}

When the SWAT model is simulated, the soil data required mainly includes two types: chemical attribute data and physical attribute data. The chemical attribute is optional data and chemical attributes of the soil are mainly used to assign the initial values to the model; the physical attribute is required, the physical attributes of the soil play an important role in water cycle of the hydrologic response unit, which determines the movement conditions of water and air in the soil profile. Before simulation, the hydrological and water conductivity attributes of various soils should be input into the SWAT model and divided into two parameter types, which are input by the soil type and soil layer. The soil particle size composition, soil layer and organic matter content used in the research can be found in Ningxia Soil. The international system standards and Kaczynski system are used for soil texture in China, and the soil particle size standard used in the SWAT model is the American system, therefore, the domestic data cannot be directly used in the SWAT model and the soil particle size should be converted from the international system to American system. The two classification criteria are shown in Table 3 and the conversion is required. There are different methods 
for soil texture conversion. Generally, the soil particle size distribution model in the parametric form is more suitable for general model, because it is more convenient for establishment of standard procedures and comparison and unification of particle size analysis data from the different sources. The empirical logic growth model of the twoparameter correction is used to convert the soil texture in this paper. The LevenbergMarquardt+ general global optimization algorithm of the nonlinear fitting program in the 1STOPT software is used, and the values of the parameters $u$ and $c$ are obtained by the relevant regression iteration, and the content of clay, silt, sand, rock (gravel) is finally determined. Other soil parameters such as soil bulk density, effective field capacity and saturated hydraulic conductivity are calculated using the Soil-WaterCharacteristics (SWCT) module in the soil water properties software SPAW developed by Washington State University. The soil erosivity factor can be calculated based on the known soil organic carbon and particle composition data and by using the soil erodibility factor $\mathrm{K}$ estimation method in the EPIC model.

Table 3. Soil particle size classification

\begin{tabular}{cc|cc}
\hline \multicolumn{2}{c|}{ International system } & \multicolumn{2}{c}{ American system } \\
\hline $\begin{array}{c}\text { Particle size range } \\
(\mathbf{m m})\end{array}$ & Name & $\begin{array}{c}\text { Particle size range } \\
(\mathbf{m m})\end{array}$ & Name \\
\hline$>2$ & Rock & $>2$ & Rock \\
$0.2-2$ & Coarse sand & $0.05-2$ & Sand \\
$0.02-0.2$ & Fine sand & $0.002-0.05$ & Silt \\
$0.002-0.02$ & Silt & $<0.002$ & Clay \\
$<0.002$ & Clay & & \\
\hline
\end{tabular}

\section{Weather data}

The daily weather data required for SWAT model stimulation includes the following: maximum temperature, minimum temperature, rainfall, wind speed, solar radiation and relative humidity etc. If the measured data is partially missing, the SWAT model defines the weather generator used to supplement the missing data. The weather generator requires input of meteorological data related to the basin and monthly meteorological data for at least 20 years, mainly including monthly average maximum temperature $\left({ }^{\circ} \mathrm{C}\right)$, monthly average minimum temperature $\left({ }^{\circ} \mathrm{C}\right)$, maximum temperature standard deviation, minimum temperature standard deviation, monthly average rainfall $(\mathrm{mm})$, monthly average rainfall standard deviation, rainfall skewness coefficient, monthly number of dry days (dry d), monthly number of wet days (wet d), average rain days (d), dew point temperature $\left({ }^{\circ} \mathrm{C}\right)$, monthly average solar radiation $\left[\mathrm{KJ} /\left(\mathrm{m}^{2} . \mathrm{d}\right)\right]$, monthly average wind speed $(\mathrm{m} / \mathrm{s})$ and maximum half-hour rainfall $(\mathrm{mm})$.

The daily observation data of Ningxia Zhongning, Yinchuan, Huinong and Taole for 23 consecutive years from 1995 to 2017 is used in this paper, including daily maximum/minimum temperature, rainfall, wind speed, relative humidity, etc. The above data is processed in .dbf format required for SWAT model. If the weather generator is used to calculate the parameters one by one, the workload is complicated; however, the simple and easy-to-operate calculation program SwatWeather.exe saves a lot of working time for the model users. As long as the files are input in required format, the required data can be calculated and saved according to the prompts. 


\section{Division of hydrological response unit}

When the SWAT model was used for simulation in the past, the hydrological response units were divided basically based on natural basins; however, the irrigation network in Ningxia section of Yellow River Basin was completely completed by artificial canals and the irrigation districts along Yellow River currently have 17 large and medium-sized diversion main canals and main canals. In this paper, based on the actual situation of the Ningxia section of the Yellow River Basin, the artificial canal network is used as the water system to divide the Ningxia section of the Yellow River Basin into several hydrological response units based on the division principles of hydrological response units.

\section{Results}

The SWAT model needs to perform the sensitivity analysis according to the actual situation of the research area, and analyze and judge which input parameter values are sensitive to the output results. The analog value of the model is close to the measured value by adjusting these parameter values. The SWAT model parameter analysis module is used to continuously adjust the parameters in the model. The adjustment process should analyze and determine which parameters are sensitive to the results and the degree of influence on the simulation results based on the actual situation and the parameter thresholds, which will make the simulation more accurate. After the sensitivity analysis on the model input parameters, the measured series data is subsequently divided into two parts, one part is used for model parameter calibration and the other part is used for model validation. After completing the model parameter calibration, the measured series data and simulated data are analyzed and compared to judge whether the simulation accuracy meets the requirements; the model applicability and reliability is validated, if the simulation value meets the requirements, the model can be used for hydrological simulation of the Ningxia section of the Yellow River Basin. In the basin simulation, the parameters sensitive to the runoff simulation results include the soil evaporation compensation coefficient $E S C O$, the number of runoff curves $\mathrm{CN}_{2}$ and the available water amount in the soil.

In the SWAT model simulation process, the relative error $R_{e}$, correlation coefficient $R^{2}$ and Nash-Suttcliffe coefficient Ens are generally selected to evaluate the model applicability. The relative error calculation formula is as below:

$$
R_{e}=\frac{Q_{p}-Q_{0}}{Q_{0}} \times 100 \%
$$

where $R_{e}$ represents the relative error of model simulation; $Q_{0}$ represents the measured value; $Q_{p}$ represents the stimulated value. If $R_{e}>0$, it indicates that the model simulation value or predicted value is too large; if $R_{e}<0$, it indicates that the model simulation value or predicted value is too small; if $R_{e}=0$, it indicates that the simulation result matches with the measured value. The correlation coefficient $R^{2}$ is obtained by using the linear regression method in Excel. If $R^{2}=1$, it indicates that the results are very matched; when $R^{2}<1$, the smaller the value, the lower the degree of 
data matching.

The calculation formula of Nash-Suttcliffe coefficient Ens is as below:

$$
E n s=1-\frac{\sum_{i=1}^{n}\left(Q_{0}-Q_{p}\right)^{2}}{\sum_{i=1}^{n}\left(Q_{0}-Q_{\text {avg }}\right)^{2}}
$$

where $Q_{0}$ is the measured value; $Q_{p}$ is the stimulated value; $Q_{a v g}$ is the measured average value; $n$ is the number of measured data. When $Q_{0}=Q_{p}$, it indicates that the measured value is well matched with the stimulated value; if $E n s<0$, it indicates that the model simulation average value has a lower reliability than directly using the measured average value.

\section{Model parameter calibration}

The SWAT model parameter calibration can be conducted by using the "Brute Force" method in two stages. In the first stage, the step size to be calibrated is estimated and the parameter value is appropriately adjusted based on the estimated step size and within the value range, subsequently the parameter is calibrated and the parameter optimal value range is determined by calculating and evaluating the system values; in the second stage, the initially estimated parameter adjustment step size is further refined. As some variables have the great impacts on the results at the initial model operation period, for example, the initial value of soil water content is zero, which has a great impact on the simulation results. Therefore, for this case, the initial simulation period is used as the model operation start period to reasonably estimate the initial variables of the model. The digital filtering technique is used to divide the measured total runoff into the base flow and the direct runoff. The difference between the model simulation value and measured value and its percentage with the measured average value (relative error) should be within the specified range and the evaluation coefficient $R^{2}$ and Ens of the monthly average stimulated value should also meet the specified accuracy standards. If the measured value and stimulated values meet the calibration requirements, but $R^{2}$ and Ens do not meet the requirements, the inspection should be conducted and the full consideration should be taken on spatial non-uniformity of simulated rainfall and correct stimulation of plant growing season. For the runoff parameter calibration, the annual average error between the simulated and measured values should be less than $20 \%$ of the measured value, and the evaluation coefficient of the monthly average value is $R^{2}>0.6$ and Ens $>0.5$; after the base flow parameter calibration, the same evaluation method is used to the surface runoff for parameter calibration. Considering that the total runoff parameter adjustment will affect the base flow, the base flow should be re-inspected continuously in the adjustment process.

In this paper, the measured monthly runoff data of Qingtongxia Hydrological Station and Shizuishan Hydrological Station from 2005 to 2011 are used for model parameters adjustment. Figs. 2 and 3 show the comparison between the measured and simulated values of the monthly runoff of the Qingtongxia Hydrological Station and the Shizuishan Hydrological Station in the calibration period. 


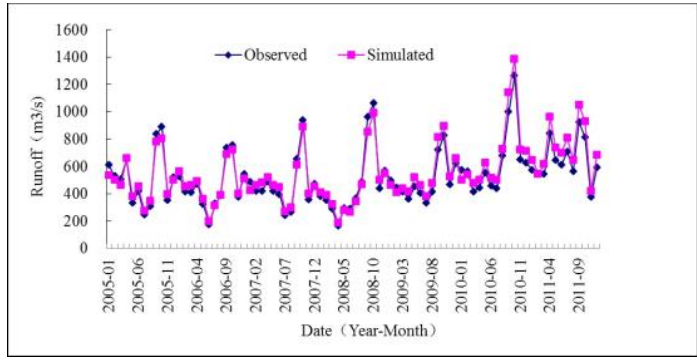

a, Qingtongxia Station

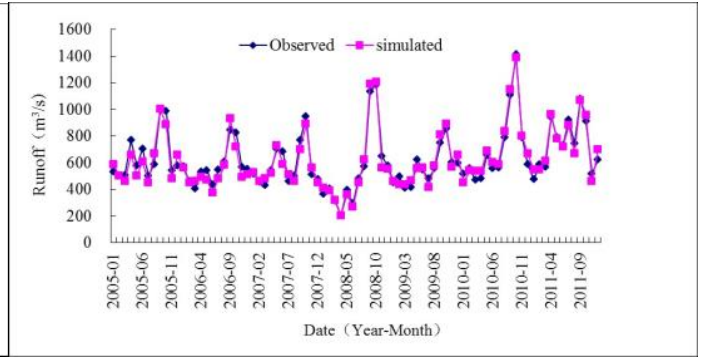

b, Shizuishan Station

Figure 2. Comparison of stimulated and observed monthly runoff for the calibration period

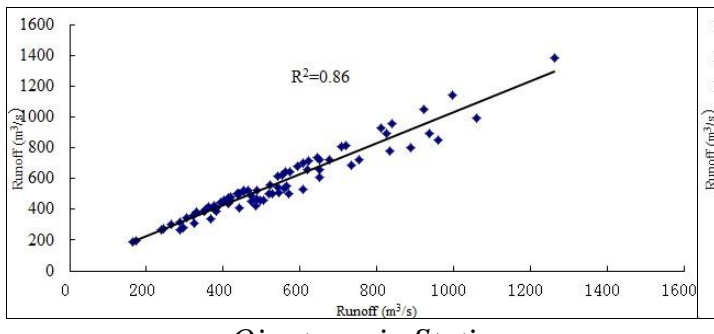

a, Qingtongxia Station

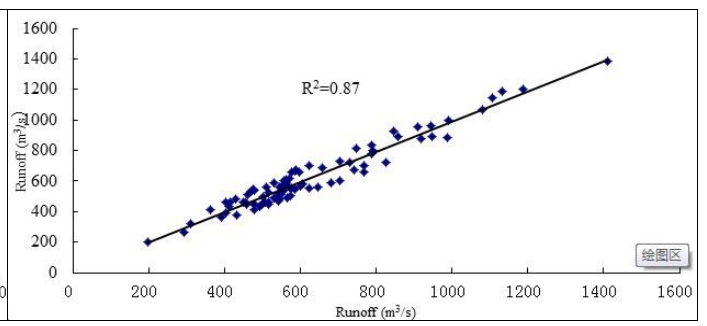

b, Shizuishan Station

Figure 3. Scatter diagram of stimulated and observed monthly runoff for the calibration period

\section{Model validation}

The observed monthly runoff data of Qingtongxia Hydrological Station and Shizuishan Hydrological Station from 2012 to 2017 are used for model validation, the parameters obtained in the model parameter calibration process are used and the relative error $R_{e}$, correlation coefficient $R^{2}$ and Nash-Suttcliffe coefficient Ens are used to evaluate the model validation results. Figs. 4 and 5 show the fitting comparison of the observed values and simulated values of monthly runoff of Qingtongxia Hydrological Station and the Shizuishan Hydrological Station in the validation period.

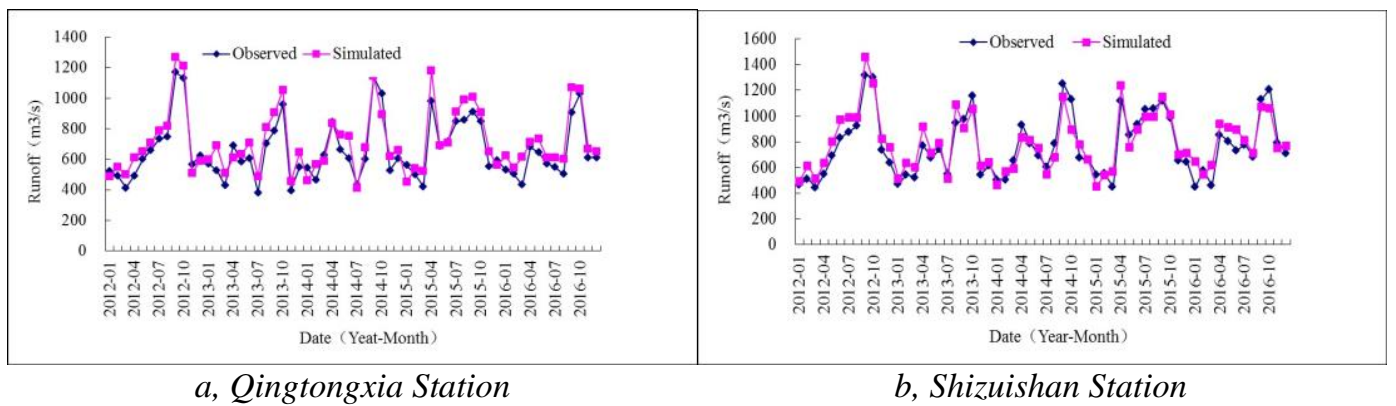

Figure 4. Comparison of stimulated and observed monthly runoff for the validation period

The relative error $R_{e}$ is between $-13.23 \%$ and $14.67 \%$; the monthly average runoff correlation coefficient $R^{2}$ and The Nash-Suttcliffe coefficient Ens are 0.88 and 0.86 respectively. For the fitting comparison of the observed values and simulated values of monthly runoff of the Shizuishan Hydrological Station, the relative error $R_{e}$ is between 
$-12.09 \%$ and $13.97 \%$; the monthly average runoff correlation coefficient $R^{2}$ and the Nash-Suttcliffe coefficient Ens are 0.89 and 0.85 respectively. The simulated and observed values of the model have a small difference and meet the simulation requirements.

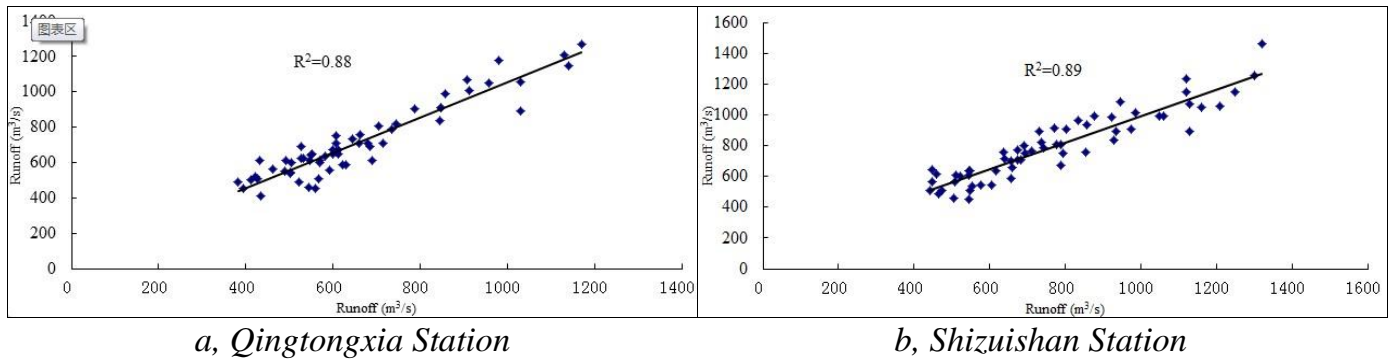

Figure 5. Scatter diagram of stimulated and observed monthly runoff for the validation period

\section{Discussion}

In the calibration period, as can be known from the Figs. 2 and 3, the simulated and measured values of the Qingtongxia Hydrological Station are approximately in the same change trend, the peak value has the higher matching degree and the relative error $R_{e}$ is between $-12.98 \%$ and $14.58 \%$; the monthly average runoff correlation coefficient $R^{2}$ and the Nash-Suttcliffe coefficient Ens are 0.86 and 0.83 respectively. The change trend of simulated value and measured value of the monthly runoff of Shizuishan Hydrological Station is well matched, the peak value has a higher marching degree and the relative error $R_{e}$ is between $-11.98 \%$ and $13.14 \%$; the monthly average runoff correlation coefficient $R^{2}$ and the Nash-Suttcliffe coefficient Ens are respectively 0.87 and 0.84 . Both meet the simulation evaluation requirements.

In the validation period, for the fitting comparison of the observed values and simulated values of monthly runoff of the Qingtongxia Hydrological Station, the relative error $R_{e}$ is between $-13.23 \%$ and $14.67 \%$; the monthly average runoff correlation coefficient $R^{2}$ and The Nash-Suttcliffe coefficient Ens are 0.88 and 0.86 respectively. For the fitting comparison of the observed values and simulated values of monthly runoff of the Shizuishan Hydrological Station, the relative error $R_{e}$ is between $-12.09 \%$ and $13.97 \%$; the monthly average runoff correlation coefficient $R^{2}$ and the Nash-Suttcliffe coefficient Ens are 0.89 and 0.85 respectively. The simulated and observed values of the model have a small difference and meet the simulation requirements.

\section{Conclusion}

In this paper, the GIS software is used for to cutting, projection transformation and reclassification of DEM, land use and soil data for Ningxia Yellow River Irrigation District, and convert these data formats into Grid format required for the model; based on the actual situation of Ningxia Yellow River Irrigation District, a attribute database such as meteorological, hydrological, and soil physical attributes required for the SWAT model is established. The constructed SWAT model is used for hydrological 
simulation of Ningxia section of the Yellow River Basin, the observed monthly runoff data of Qingtongxia Hydrological Station and Shizuishan Hydrological Station from 2005 to 2017 are used for model parameters sensitivity analysis, calibration and validation and continuous adjustment, the relative error $R_{e}$, correlation coefficient $R^{2}$ and Nash-Suttcliffe coefficient Ens are used for model applicability evaluation. The results show that the observed values and stimulated values of monthly runoff of Qingtongxia Hydrological Station and Shizuishan Hydrological Station in the calibration period are approximately in the same change trend, the peak value has the higher matching degree, for Qingtongxia Hydrological Station, the relative error $R_{e}$ is between $-12.98 \%$ and $14.58 \%$, the monthly average runoff correlation coefficient $R^{2}$ and the Nash-Suttcliffe coefficient Ens are 0.86 and 0.83 respectively. For Shizuishan Hydrological Station, the relative error $R_{e}$ is between $-11.98 \%$ and $13.14 \%$ and the monthly average runoff correlation coefficient $R^{2}$ and the Nash-Suttcliffe coefficient Ens are respectively 0.87 and 0.84 . The observed values and stimulated values of monthly runoff of Qingtongxia Hydrological Station and Shizuishan Hydrological Station in the validation period have the small difference, for Qingtongxia Hydrological Station, the relative error $R_{e}$ is between $-13.23 \%$ and $14.67 \%$ and the monthly average runoff correlation coefficient $R^{2}$ and The Nash-Suttcliffe coefficient Ens are 0.88 and 0.86 respectively. For Shizuishan Hydrological Station, the relative error $R_{e}$ is between $-12.09 \%$ and $13.97 \%$ and the monthly average runoff correlation coefficient $R^{2}$ and the Nash-Suttcliffe coefficient Ens are 0.89 and 0.85 respectively. The simulated and observred values of the model have a small difference and meet the simulation requirements. The constructed SWAT model is suitable for the hydrological process simulation of the Ningxia Yellow River Irrigation District, which lays the foundation for the subsequent water supply prediction.

Acknowledgements. The study was completed with the support of the First-class Major Foundation of Ningxia Institutions of High Education in China. (NXYLXK2017A03).

\section{REFERENCES}

[1] Amon-Armah, F., Yiridoe, E. K., Ahmad, N. H., Hebb, D., Jamieson, R., Burton, D., Madani, A. (2013): Effect of nutrient management planning on crop yield, nitrate leaching and sediment loading in thomas brook watershed. - Environ. Manage. 52(5): 1177-1191.

[2] Armanini, D. G., Horrigan, N., Monk, W. A., Peters, D. L., Baird, D. J. (2011): Development of a benthic macroinvertebrate flow sensitivity index for Canadian rivers. River Res. Appl. 27: 723-737.

[3] Arnold, J. G., Srinisvan, R., Muttiah, R. S., Williams, J. R. (1998): Large area hydrologic modeling and assessment. Part I: model development. - Journal of the American Water Resources Association 34(1): 73-89.

[4] Biggs, B. J. F., Kilroy, C., Mulcock, C. M., Scarsbrook, M. R. (2002): New Zealand stream health monitoring and assessment kit. - Stream Monit. Man., Version 2. NIWA Technical Report 111.

[5] Chow, V. T., Maidment, D. R., Mays, L. W. (1988): Applied Hydrology. Berkshire. McGraw- Hill Book Co (UK) Ltd. 
[6] Dechmi, F., Burguete, J., Skhiri, A. (2012): SWAT application in intensive irrigation systems: model modification, calibration and validation. - J. Hydrol. s470-471 (14): 227238.

[7] Fohrer, N., Möller, D., Steiner, N. (2017): An Interdisciplinary Modeling Approach to Evaluate the Effects of Land Use Change. - Journal of Hydrology 2: 46-57.

[8] Godlewska, M., Mazurkiewicz-Boron, G., Pociecha, A., Wilk-Wozniak, E., Jelonek, M. (2003): Effects of flood on the functioning of the Dobczyce reservoir ecosystem. Hydrobiologia 3(1): 305-313.

[9] Joel, N., Jiben, J. (2012): Hydrological Response of Watershed Systems to Land Use /Cover Change, a Case of Wami River Basin. - The Open Hydrology Journal 6(1): 78-87.

[10] Leavesley, G. H., Lichty, R. W., Troutman, B. M., Saindon, L. G. (1983): PrecipitationRunoff Modelling System. - User's manual, Denver, USA.

[11] Lin, B., Chen, X., Yao, H., Chen, Y., Liu, M., Gao, L., James, A. (2015): Analyses of landuse change impacts on catchment runoff using different time indicators based on SWAT model. - Ecological Indicators 58: 55-63.

[12] Liu, R., Zhang, P., Wang, X., Chen, Y., Shen, Z. (2013): Assessment of effects of best management practices on agricultural non-point source pollution in Xiangxi River watershed. - Agric. Water Manage 117(1): 9-18.

[13] Liu, R., Zhang, P., Wang, X., Wang, J., Yu, W., Shen, Z. (2014): Cost-effectiveness and cost-benefit analysis of BMPs in controlling agricultural nonpoint source pollution in China based on the SWAT model. - Environ. Monit. Assess 186(12): 9011-9022.

[14] Liu, R., Xu, F., Liu, Y., Wang, J., Yu, W. (2016): Spatio-temporal characteristics of livestock and their effects on pollution in China based on geographic information system. - Environ. Sci. Pollut. Res: 1-13.

[15] Liu, R., Wang, Q., Xu, F., Men, C., Guo, L. (2017): Impacts of manure application on SWAT model outputs in the Xiangxi River watershed. - Journal of Hydrology 555: 479488.

[16] Lotz, T., Opp, C., He, X. (2018): Factors of runoff generation in the Dongting Lake basin based on a SWAT model and implications of recent land cover change. - Quaternary International 475: 54-62.

[17] Maharjan, G. R., Ruidisch, M., Shope, C. L., Choi, K., Huwe, B., Kim, S. J., Tenhunen, J., Arnhold, S. (2016): Assessing the effectiveness of split fertilization and cover crop cultivation in order to conserve soil and water resources and improve crop productivity. Agric. Water Manage 163: 305-318.

[18] Nie, W., Yuan, Y., Kepner, W. (2011): Assessing Impacts of Land Use and Land Cover Changes on Hydrology for the Upper San Pedro Watershed. - Journal of Hydrology 407( 4): $105-114$.

[19] Schuol, J., Abbaspour, K. C., Srinivasan, R., Yang, H. (2008): Estimation of Freshwater Availability in the West African Sub-Continent Using the SWAT Hydrologic Model. Journal of Hydrology 352(2): 30-49.

[20] Sokal, M. A., Hall, R. I., Wolfe, B. B. (2010): The role of flooding on inter-annual and seasonal variability of lake water chemistry, phytoplankton diatom communities and macrophyte biomass in the Slave River Delta (Northwest Territories, Canada). Ecohydrology 3(1): 41-54.

[21] Tamm, O., Maasikamae, S., Padari, A., Tamm, T. (2018): Modelling the effects of land use and climate change on the water resources in the eastern Baltic Sea region using the SWAT model. - Catena 167: 78-89.

[22] US EPA. (2015): Identifying and Protecting Healthy Watersheds. - EPA technical document. EPA Office of Wetlands, Oceans, and Watersheds, Washington, DC, http://water.epa.gov/ healthywatersheds.

[23] Viessman, W. J., Lewis, G. L., Knapp, J. W. (1989): Introduction to Hydrology, third ed. - Harper and Row Publishers, New York, 491-670. 
[24] Woessner, W. W. (2012): Formulating, applying and constraining hydrological models: modeling 101. - In: Water Center and School of Natural Resources Seminar. University of Nebraska, USA, 1-65.

[25] Wu, H. P., Zeng, G. M., Liang, J., Guo, S. L., Dai, J., Lu, L. H., Wei, Z., Xu, P., Li, F., Yuan, Y. J., He, X. X. (2015): Effect of early dry season induced by the Three Gorges Dam on the soil microbial biomass and bacterial community structure in the Dongting Lake wetland. - Ecol. Indic. 53: 129-136.

[26] Xu, C. (2002):Text book of hydrological models. - In: Xu, C. (Ed.), Uppsala (Sweden). Uppsala University Department of Earth Sciences Hydrology. 